Diffusion und chemische Reaktion in festen Stoffen Von Prof. Dr. Wilhelm Jost. (Die chemische Reaktion, herausgegeben von K. F. Bonhoeffer und H. Mark, Band 2.) Pp. viii + 231. (Dresden und Leipzig: Theodor Steinkopff, 1937.) 20 gold marks.

THE present book deals with a number of phenomena which are of importance in modern physical chemistry. The chapters deal with diffusion processes in the solid state, irregularities in lattices (Fehlordnung), the elementary processes in solid reactions, tarnish, and general reactions in the solid state. Although the literature is fairly well covered, there is more emphasis on modern work, including English and American. The field covered is limited, so that many topics such as recrystallization are excluded, but those parts selected for treatment are chosen judiciously and are dealt with in a very critical and systematic way. A good feature is the close relation which is established between the theoretical principles (which are very clearly stated) and the experimental results. The book is a well presented and accurate survey of an interesting subject.

Reagent Chemicals and Standards:

with Methods of Assaying and Testing them; also the Preparation and Standardization of Volumetric Solutions and Extensive Tables of Equivalents. By Joseph Rosin. Pp. $\mathrm{x}+$ 530. (London: Chapman and Hall, Ltd., 1937.) 30s. net.

THERE are comparatively few books which deal 1 with the standards and specifications for chemical reagents and, if only for this reason, the treatise under review would be acceptable; it is, however, doubly welcome in that it provides the most complete treatment of the subject hitherto produced. Nearly five hundred substances are listed, these including many of the newer organic chemicals and indicators. Assays are provided in most cases for the major constituent as well as for the likely impurities, while tables are given of the maximum tolerance permitted for the latter. There is also a useful section on the preparation and standardization of volumetric solutions, together with extensive tables of equivalents and gravimetric factors.

\section{A Note-Book of Tropical Agriculture}

Compiled by Prof. R. Cecil Wood. Second edition. Pp. iv +147. (Trinidad: Imperial College of Tropical Agriculture, 1937.) $5 s$.

THIS is a small book that can be wholeheartedly recommended. It is a development of a small compilation which the author made while he was in India, and now he has added the results of his experience in Africa and in the West Indies. Of course, many of the data given have no special reference to the tropics, but the really valuable part of the book is that dealing with tropical materials and especially with tropical crops, about which it is somewhat difficult to get information. The book cannot fail to be of value to all who are proceeding to positions connected with agriculture in any part of the tropics.

\section{Florae Siamensis Enumeratio:}

a List of the Plants known from Siam, with Records of their Occurrence. By the late Prof. W. G. Craib. Edited by A. F. G. Kerr. Vol. 2, Part 4 : Vacciniaceæ to Styraceæ. Pp. 311-393. (Bangkok : The Bangkok Times Press, Ltd.; London : Luzac and Co., 1938.) 7 tes.; 12s. $10 d$.

STUDENTS of Asiatic botany will weleome the $S$ appearance of Vol. 2, Part 4, of this work. The "Enumeratio" was commenced in 1925 by the late Prof. G. W. Craib, and since his death Dr. A. F. G. Kerr has carried on the work.

The present volume, which is arranged on the Bentham and Hooker system, contains the families Vacciniaceæ to Styraceæ. A glance at the names of the collectors and of the authors of new species shows how greatly we are indebted to Prof. Craib, Dr. Kerr and their co-workers for our knowledge of the flora of Siam. The issue of further parts will be awaited with interest.

\section{Nationalism and the Communal Mind}

By Dr. E. Hanbury Hankin. Pp. xv + 199. (London : Watts and Co., Ltd., 1937.) 7s. 6d. net.

D. HANKIN'S approach to the problem of nationalism, and his examination of the causes which underlie the sporadic and periodic outbursts of this expression of the communal mind, are of considerable interest to the anthropologist and the alienist. Like other inquirers, he traces it to the blood bond, but in a different sense. He associates it with the group of customs of primitive peoples at the head of which are cannibalism, head-hunting and the like, and behind which are the magical or mystical conceptions of assimilation of power, whether from enemy or friend. In support of the contention that primitive ideas of this type may survive deep down in the subconscious of the communal mind, the sporadic resurgence of cannibalism and other forms of the blood lust would appear to lend a measure of support.

Die Leuchtmassen und ihre Verwendung: eine Einführung in Fluoreszenz und Phosphoreszenz der festen Körper. Von Dr. Henriette Rupp. Pp. vi $+163+2$ plates. (Berlin: Gebrüder Borntraeger, 1937.) 8 gold marks.

DHOSPHORESCENCE has so many modern applications and is of such fundamental significance in connexion with the theory of the solid state, that the appearance of this well-written and comprehensive account of it is very welcome. Dr. Rupp describes the methods used to excite and analyse phosphorescent light, and gives an outline of the principal uses of phosphorescent bodies and the theories of phosphorescence. Her book is particularly valuable from the orderly way in which phenomena are classified, permitting of quick reference to any particular aspect of the subject, and for the detailed accounts provided of the preparation of some materials of technical importance. It includes a short history of phosphorescence, and a bibliography of recent publications. 